\title{
Apoptosis and Mitochondrial Damage in INS-1 Cells Treated with Alloxan
}

\author{
Koichi SaKurai,* Mika Katoh, Kimio Someno, and Yukio Fujimoto \\ Department of Biochemistry, Hokkaido College of Pharmacy, 7-1 Katsuraoka-cho, Otaru, Hokkaido 047-0264, Japan. \\ Received January 18, 2001; accepted May 8, 2001
}

\begin{abstract}
To evaluate the participation of mitochondrial damage, oxygen radicals and cell death in diabetes mellitus, we designed a way to investigate INS-1 cells, rat pancreatic $\beta$-cell line, to die by treatment with alloxan which generate reactive oxygen species (ROS). Incubation of INS-1 cells with alloxan for $24 \mathrm{~h}$ resulted in a decrease in viability of cells as well as inhibition of glucose-stimulated insulin release; this could be prevented by antioxidants, vitamin $\mathrm{E}$ and butylated hydroxyanisol (BHA). The formation of a DNA ladder and the distribution of phosphatidylserine at the external surface of plasma membrane were observed as indicators of apoptosis in the cells treated with alloxan at concentrations below $0.5 \mathrm{~mm}$. The formation of DNA ladder was prevented by vitamin E, BHA and catalase, suggesting that the ROS is involved in the process of apoptosis in INS-1 cells treated with alloxan. Lower levels of intracellular ATP, collapse of mitochondrial membrane potential and release of cytochrome $\mathrm{c}$ from mitochondria were also observed in INS-1 cells treated with alloxan, suggesting that alloxan caused the damage of mitochondria in cells and was related to the process of apoptosis. In contrast, rat liver RLC-18 cells treated with alloxan were not observed in the decrease of viability. It follows from the present study that mitochondrial damages by ROS generated from alloxan is linked to apoptosis in INS-1 cells.
\end{abstract}

Key words alloxan; apoptosis; mitochondria; reactive oxygen species; INS-1 cell; diabetes

A variety of mechanisms have been identified as responsible for the onset of diabetes mellitus. Alloxan shows a selective cytotoxicity on pancreatic $\beta$-cells and thus causes insulin-dependent (type I) diabetes mellitus. Although the mechanism of alloxan cytotoxicity is not yet clearly understood, several researchers ${ }^{1,2)}$ demonstrated that the diabetogenic action was initiated by the generation of reactive oxygen species (ROS). Alloxan is a mild oxidant and is easily reduced to alloxan radicals $\left(\mathrm{A}^{-}\right)$by GSH or ascorbic acid. $\left.{ }^{3}\right)$ Our previous study ${ }^{4)}$ demonstrated that $\mathrm{A}^{-}$can directly reduce $\mathrm{O}_{2}$ and ferric ions to superoxide anion radical $\left(\mathrm{O}_{2}^{-}\right)$and ferrous ions, respectively. The extreme and indiscriminate reactivity of ROS could easily explain the killing of $\beta$-cells by alloxan. In support of this hypothesis alloxan diabetes is prevented by $\mathrm{HO} \cdot$ scavengers, ${ }^{5-7)}$ superoxide dismutase $(\mathrm{SOD})^{2)}$ and vitamin $\mathrm{E}^{8)}$ In addition, on the basis of in vivo and in vitro studies using rats and isolated islet cells, respectively, it was proposed that the process of alloxan toxicity involved the generation of $\mathrm{HO} \cdot$ by which the DNA strands break of pancreatic islets is attacked to produce. ${ }^{9-11)}$ These findings indicate that DNA strand breaks are involved in the events of alloxan-diabetogenesis. However, the complex sequence of events that eventually leads to the DNA strand breaks and death of pancreatic $\beta$-cells in alloxan diabetes mellitus is not clear.

Cell death might occur by one of two fundamental processes, necrosis or apoptosis. The biochemical hallmarks of apoptosis are the distribution of phosphatidylserine (PS) at the external surface of the plasma membrane (PS exposure) in the early stages, and the cleavage of chromosomal DNA into nucleosomal units, which appears to be the final blow in the cell death process. Recent studies have shown that different trigger such as IL-1 $\beta^{12)}$ and streptozotocin ${ }^{13)}$ can induce apoptosis in pancreatic $\beta$-cells. Although detailed studies indicate that alloxan can induce insulin-dependent diabetes mellitus, nothing is known about apoptotic action or the sequence of cellular events of alloxan on the $\beta$-cells.

According to current understanding, mitochondrial dam- age seems to occur in the early phase of apoptosis and to participate in the control of apoptosis. ${ }^{14,15)}$ Release of cytochrome $\mathrm{c}$ and apoptosis induced factor from mitochondria into cytoplasm during mitochondrial permeability transition cause to active caspase family, leading to the completion of apoptosis. $^{15,16)}$ Isolated liver mitochondria incubated with alloxan alters respiration, decreases in the concentration of adenine nucleotides, causes $\mathrm{Ca}^{2+}$ release, and changes in the $\Delta \psi,{ }^{17,18)}$ indicating that alloxan directly induces the mitochondrial damage. However, the relationship between diabetes, apoptosis and mitochondrial damage has remained elusive.

INS-1 cells were established by X-ray-induced rat transplantable insulinoma, and have retained the similar ability of glucose-stimulated insulin release of native $\beta$-cells. ${ }^{19)}$ INS-1 cells were used in this experiment since they are much easier to obtain than native pancreatic $\beta$-cells and also have sensitivity to alloxan..$^{20,21)}$ It is therefore reasonable to use the INS-1 cells for the elucidation of alloxan diabetes.

Our hypothesis was that alloxan may result in oxidative damage to mitochondria, and the damage participates in the apoptotic death of pancreatic $\beta$-cells. To confirm this hypothesis, we studied the effect of alloxan on viability, DNA fragmentation, insulin release and $\Delta \psi$ of INS- 1 cells and modulation of these effects by antioxidants.

\section{MATERIALS AND METHODS}

Chemicals Fetal calf serum (FCS), RPMI-1640 medium and other cell culture reagents were obtained from Sigma Chemical Co., St. Louis, MO, U.S.A. 3-(4,5-Dimethylthiazol-2-yl)-2,5-diphenyltetrazolium (MTT) assay kit was from Promega Co., Madison, WI, U.S.A. Insulin assay kit was from Wako Pure Chem., Ltd., Japan. ATP assay kit was from Boehring Mannheim, Indianapolis, IN, U.S.A. The mitochondrial membrane sensor kit was from Clontech Laboratories, Inc. CA, U.S.A. All other chemicals were used in this experiment the highest grade from commercial suppliers. 
Culture and Cytotoxicity INS-1 cells were the kind gift of Dr. C. B. Wollheim and were grown in plastic culture vessels in an incubator in an atmosphere of $5 \% \mathrm{CO}_{2}-95 \%$ air at $37^{\circ} \mathrm{C}$ as described by Asfari et al. ${ }^{19)}$ Cells were subcultured at a $1: 3$ ratio once a week, cell number was determined by counting with a hemocytometer. Rat liver RLC-18 cells originally developed by Takaoka et al., ${ }^{22)}$ were obtained from the Riken Cell Bank (Wako) and grown in DM160-AU medium (Kyokuto Pharmaceutical Ind. Co., Ltd., Tokyo, Japan) with $2 \%(\mathrm{v} / \mathrm{v})$ FCS. The cells were subcultured at a $1: 4$ ratio once a week. Other culture conditions were the same as these of INS-1 cells.

Cytotoxicity of INS- 1 cells was determined using a MTT reduction assay. ${ }^{23,24)}$ INS-1 cells were seeded onto 24 well plates at a cell concentration of $2 \times 10^{5}$ cells/well in $1 \mathrm{ml}$ of RPMI-1640 medium containing $2 \%$ FCS, and were preincubated overnight. After incubation with alloxan for a designated time, usually for $24 \mathrm{~h}$, the medium was removed. To assay for MTT reduction, the medium was removed, and $575 \mu \mathrm{l}$ of RPMI- 1640 containing $2 \%$ FCS and $15 \%$ dye solution was added for $1 \mathrm{~h}$ incubation at $37^{\circ} \mathrm{C}$. Solubilization/ stop solution $(500 \mu \mathrm{l} /$ well $)$ was added to each well for at least 4 more $\mathrm{h}$ of incubation. The absorbance at $570 \mathrm{~nm}$ (formation of formazan) and $630 \mathrm{~nm}$ (reference) was recorded with a spectrophotometer (Hitachi U-2000, Tokyo, Japan).

Apoptosis Assay The formation of DNA ladder (DNA fragmentation pattern) in INS-1 cells was assessed by agarose gel electrophoresis using a minor modification of previously described protocol. ${ }^{25)}$ Cells $\left(5 \times 10^{5}\right)$ were treated with or without alloxan in the presence or absence of antioxidants as described in the figure legends.

In the early stages of apoptosis, PS which moved from the inner side of the plasma membrane to the outer layer ${ }^{26)}$ was stained using an Annexin V-FLUOS staining kit (Roche, Mannheim, Germany) according to the manufacturer's instructions. Apoptotic cells were subjected to flow cytometric analysis by means of a Coulter ELITE cytofluorometer (Beckman Coulter, Inc., Fullerton, CA, U.S.A.).

Insulin Assay INS-1 cells were seeded at a density of $5 \times 10^{5}$ cells/well in $1 \mathrm{ml}$ of RPMI-1640 medium containing $2 \%$ FCS, and were preincubated overnight. After the incubation with alloxan in the same medium, the cells were washed with Krebs-Ringer buffer (KRB) consisting of $0.12 \mathrm{M} \mathrm{NaCl}$, $5.4 \mathrm{~mm} \mathrm{KCl}, 1.2 \mathrm{~mm} \mathrm{KH}_{2} \mathrm{PO}_{4}, 1.3 \mathrm{~mm} \mathrm{CaCl} 2,1.3 \mathrm{~mm} \mathrm{MgSO}_{4}$, $20 \mathrm{~mm}$ HEPES, $24 \mathrm{~mm} \mathrm{NaHCO}$ and $1 \mathrm{mg} / \mathrm{ml}$ bovine serum albumin, and then were incubated in the same buffer containing $11 \mathrm{~mm}$ glucose to release insulin. The amount of insulin was determined by a competitive ELISA technique using an insulin assay kit with rat insulin as standard.

ATP Assay The ATP content of INS-1 cells was determined by the luciferin-firefly luciferase method. ${ }^{27)}$ Briefly, INS- 1 cells $\left(5 \times 10^{5}\right.$ cells $\left./ \mathrm{ml}\right)$ were incubated in a total volume of $1 \mathrm{ml}$ and then were incubated with alloxan as described in the legend. The cells were collected by scraping in $0.5 \mathrm{~mm}$ of Tris- $\mathrm{HCl}$ buffer, $\mathrm{pH}$ 7.4. Then, $200 \mu \mathrm{l}$ of suspension solution was used for measurement of ATP using an ATP assay kit.

Mitochondrial Membrane Potential The mitochondrial damage of INS-1 cells was detected by fluorescence microscopy for visualization using $5,5^{\prime}, 6,6^{\prime}$-tetrachloro-1,1',3,3'tetraethylbenzimidazolylcarbocyanine iodide (denote JC-1) according to a minor modification of previously described protocol. ${ }^{28)}$ Briefly, $5 \times 10^{5}$ cells $/ \mathrm{ml}$ of INS-1 cells treated with or without alloxan were incubated with $\mathrm{JC}-1$ at $37^{\circ} \mathrm{C}$ for $15 \mathrm{~min}$. To remove the unbound dye, the cells were washed once with serum-free RPMI-1640 medium. The histological alterations were immediately photographed under a fluorescent microscope (Olympus BX 50) through a hand pass filter.

Cytochrome c Release The release of mitochondrial cytochrome $\mathrm{c}$ was detected by a cytochrome $\mathrm{c}$ ELISA kit (Medical \& Biological Laboratories Co., Ltd., Nagoya, Japan). Briefly, at the end of treatment with or without alloxan, INS1 cells $\left(5 \times 10^{6}\right.$ cells $\left./ \mathrm{ml}\right)$ were collected, washed and resuspended in ice-cold homogenizing buffer $(10 \mathrm{~mm}$ Tris- $\mathrm{HCl}$ ( $\mathrm{pH} 7.5$ ), $0.3 \mathrm{~m}$ sucrose, $10 \mu \mathrm{m}$ aprotinin, $10 \mu \mathrm{m}$ pepstatin $\mathrm{A}$, $10 \mu \mathrm{m}$ leupeptin and $1 \mathrm{~mm}$ phenylmethylsulfonyl fluoride). The cells were homogenized with homogenizer (Weaton 358005, Millville, NJ, U.S.A.). The homogenate was spun at $10000 \times \boldsymbol{g}$ for $60 \mathrm{~min}$ at $4{ }^{\circ} \mathrm{C}$. The supernatant was collected and used as cytosol fraction for measurement of cytochrome c.

Statistical Analysis Data were expressed as a mean \pm S.D. and statistically analyzed by Student's $t$-test for pair data. $p<0.05$ was considered statistically significant.

\section{RESULTS}

Cytotoxicity of Alloxan In order to characterize INS-1 cell death, we first assessed the viability of INS-1 cells

A

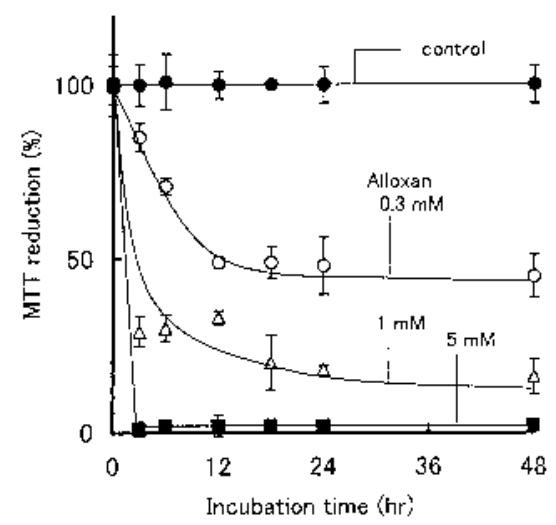

B

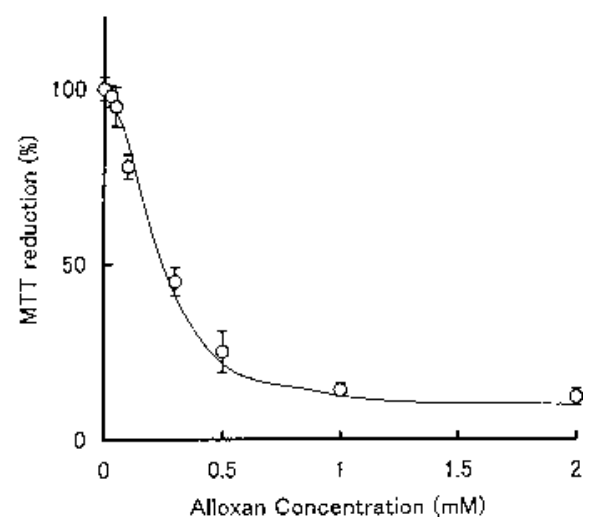

Fig. 1. Dose-Response and Time Course of Viability of INS-1 Cells Treated with Alloxan

After the addition of varying concentrations of alloxan, INS-1 cells were incubated for the indicated times (A) or $24 \mathrm{~h}$ (B), and their viability was determined by MTT assay as described in Materials and Methods. Data represent the mean \pm S.D. of three experiments. 
A

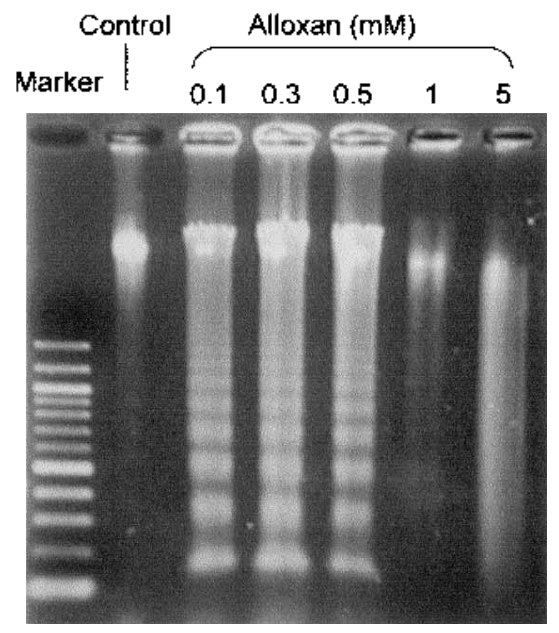

B

Control

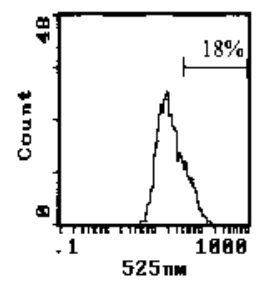

$0.3 \mathrm{mM}$

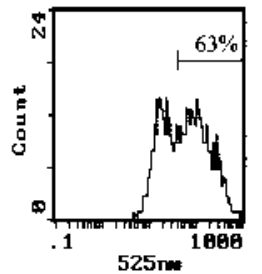

$5 \mathrm{mM}$

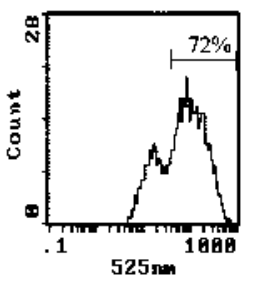

Anncxin $V$ binding fluoresccnce intensity
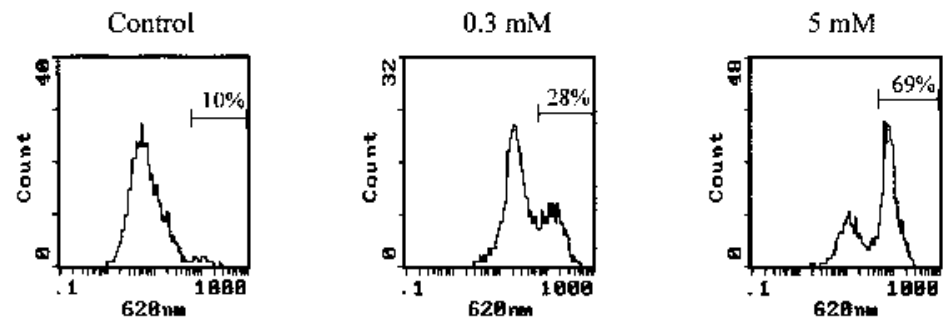

PI binding fluorescence intensity

Fig. 2. Apoptosis in INS-1 Cells Treated with Alloxan

(A) INS-1 cells were treated with varying concentrations of alloxan for $24 \mathrm{~h}$. DNA was isolated and electrophoresed as described in Materials and Methods. (B) INS-1 cells were incubated with 0.3 or $5 \mathrm{~mm}$ of alloxan for $6 \mathrm{~h}$. PS on the external surface of plasma membrane (PS exposure) was determined by annexin V-fluorescein binding (upper) and PI binding (lower) for the detection of apoptotic cells. Similar results were observed in two other independent experiments using different preparations of cells.

treated with alloxan. As shown in Fig. 1, addition of alloxan to culture medium at a concentration up to $5 \mathrm{~mm}$ caused a dose-dependent decrease in cell viability, as assessed by MTT reduction; the viabilities $24 \mathrm{~h}$ after the addition of 0.3 , 1 and $5 \mathrm{~mm}$ of alloxan were 51,21 and $5 \%$, respectively.

To determine that alloxan induces apoptotic death in INS1 cells, formation of DNA ladder and PS exposure were used as typical indexes. ${ }^{26)}$ As shown in Fig. 2 A, treatment of cells with alloxan at $0.1-0.5 \mathrm{~mm}$ for $24 \mathrm{~h}$ was observed by the formation of DNA ladder, whereas no DNA ladder could be observed with control cells. In contrast, alloxan at concentrations above $1 \mathrm{~mm}$ induced a decrease in fluorescence intensity and DNA smear. No formation of DNA ladder was observed in cells treated with alloxan at $5 \mathrm{~mm}$ for 6 - or 18 -h (data not shown). As shown in Fig. 2B, $6 \mathrm{~h}$ after $0.3 \mathrm{~mm}$ of alloxan treatment, annexin binding as an indicator of PS exposure in the early stages of apoptosis was increased from $18 \%$ in control preparations to $63 \%$ in INS-1 cells treated with alloxan. Monitoring the number of propidium iodide (PI)-positive cells showed that the treatment with alloxan marginally affected plasma membrane permeability, since the number of positive cells was less than $30 \%$. When INS-1 cells were treated with $5 \mathrm{~mm}$ of alloxan for $6 \mathrm{~h}$, annexin- and PI-positive cells were clearly visible. It should be added that similar observations were obtained at 2 and $4 \mathrm{~h}$ after $5 \mathrm{~mm}$ of alloxan treatment (data not shown). It is possible that alloxan at a concentration below $0.5 \mathrm{~mm}$ induces apoptosis.

Effect of Antioxidants on Alloxan Cytotoxicity To determine the participation of ROS in alloxan cytotoxicity, the effect of antioxidants on the cytotoxicity to INS-1 cells was investigated. As shown in Fig 3, catalase provided protection against the formation of DNA ladder in INS-1 cells treated with alloxan at a concentration of $0.3 \mathrm{~mm}$ for $24 \mathrm{~h}$, and vitamin E and BHA also provided strong protection. Slight pro- 


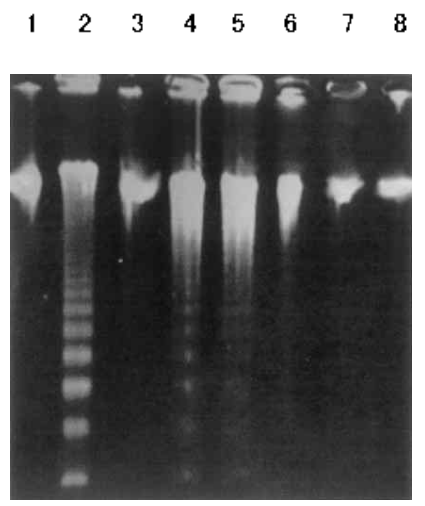

Fig. 3. Effect of Antioxidants on DNA Ladder Formation in INS-1 Cells Treated with Alloxan

INS-1 cells were incubated with (lanes $2-8$ ) or without (lane 1) $0.3 \mathrm{~mm}$ of alloxan for $24 \mathrm{~h}$ with the following additions: lanes 1 and 2, no addition; lane 3, 2000 U/ml catalase; lane 4,1000 U/ml SOD; lane 5, $5 \mathrm{~mm}$ thiourea; lane 6, $1 \mathrm{~mm} \mathrm{GSH}$; lane 7, $0.025 \mathrm{~mm}$ vitamin $\mathrm{E}$ and lane $8,0.1 \mathrm{~mm}$ BHA. Other conditions were as described in Fig. 2. Similar results were observed in two other independent experiments using different preparations of cells.

A

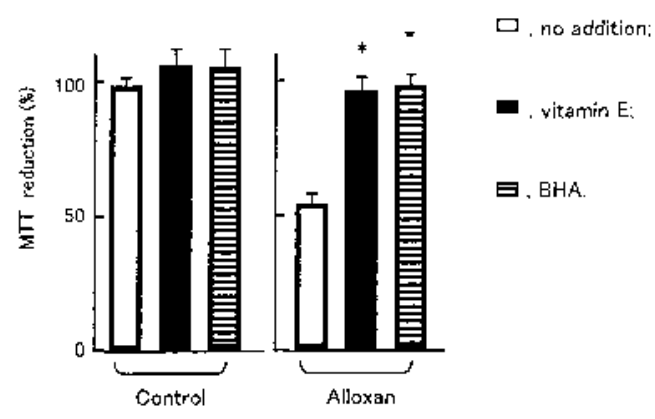

B

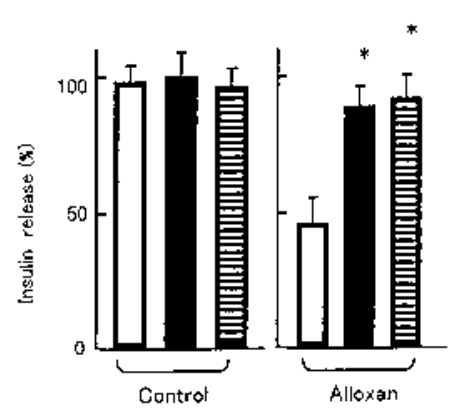

Fig. 4. Effect of Antioxidants on Lesions of INS-1 Cells Treated with Alloxan

INS- 1 cells were incubated with or without $0.3 \mathrm{~mm}$ of alloxan for $24 \mathrm{~h}$ in the presence or absence of $0.025 \mathrm{~mm}$ of vitamin E or $0.1 \mathrm{~mm}$ of BHA. Assay of MTT reduction (A) and insulin release (B) were described in Materials and Methods. Results are the mean \pm S.D. of triplicate experiments. $* p<0.05$ compared with no addition of INS- 1 cells treated with alloxan.

tection against DNA ladder formation was afforded by SOD and thiourea. Test compounds and enzymes used in this study had no effect on control cells or the electrophoresis of DNA ladder formed in cells treated with alloxan.

As shown in Fig. 4, vitamin E and BHA significantly prevented the inhibition of MTT reduction and glucose-stimulated insulin release caused by alloxan at $0.3 \mathrm{~mm}$. These results suggest that ROS mediates the cytotoxic action of alloxan at lower concentrations on INS-1 cells.

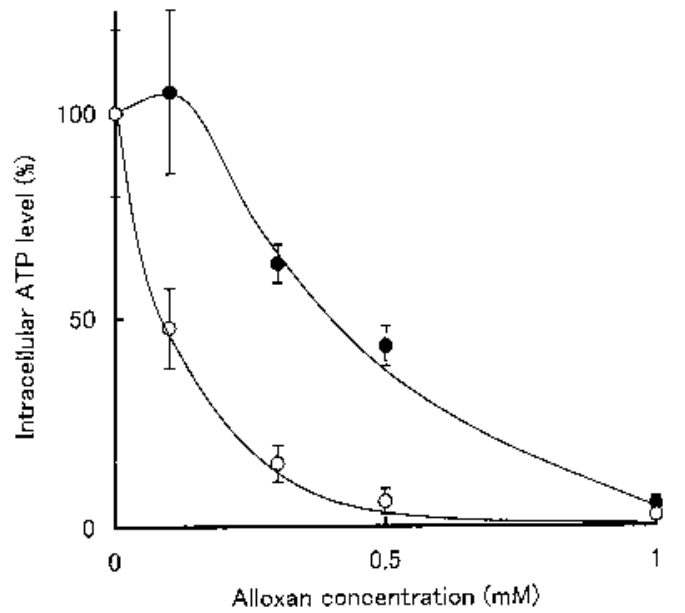

Fig. 5. Intracellular ATP Contents of INS-1 Cells Treated with Alloxan

The conditions of incubation were the same as described in the legend to Fig. 1 B, except for incubation times, 9-( ) or 24-(O) h. Data for intracellular ATP contents are presented as a percentage of the value found at time zero for each incubation. Mean value \pm S.D. for ATP contents of the INS- 1 cells was $1.62 \pm 0.28$ pmol $/ 5 \times 10^{5}$ cells. Each point represents the mean \pm S.D. of triplicate experiments.

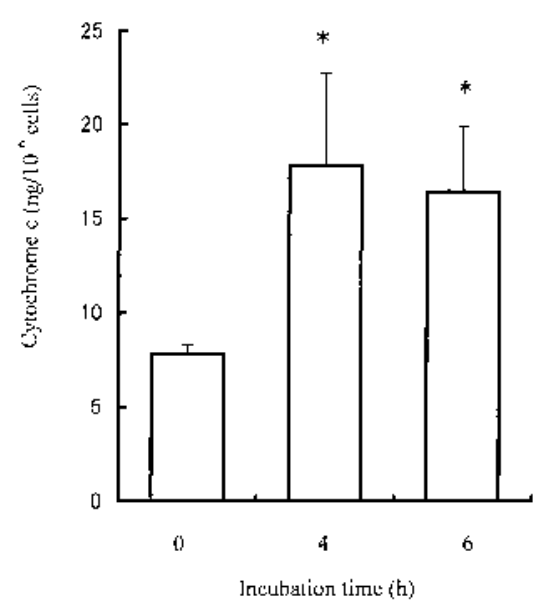

Fig. 6. Cytochrome c Release in INS-1 Cells Treated with Alloxan

INS-1 cells were treated with $0.3 \mathrm{~mm}$ of alloxan for 4- or 6-h. Cytochrome c released in cytosol of INS-1 cells was detected by ELISA assay as described in Materials and Methods. Each value represents the mean \pm S.D. of triplicate experiments. $* p<0.05$ compared with INS-1 cells untreated with alloxan.

Functional Alterations in Mitochondria Because mitochondria are implicated in the apoptosis process induced by several triggers, ${ }^{14,15)}$ alterations of mitochondria in INS-1 cells in apoptosis induced by alloxan were assessed. As shown in Fig. 5, addition of alloxan resulted in decrease of intracellular ATP amounts in a dose-dependent manner. After 9- and 18-h addition of alloxan at a concentration of $0.3 \mathrm{~mm}$, the levels of ATP in INS-1 cells were $0.92 \pm 0.08$ and $0.11 \pm$ $0.02 \mathrm{nmol} / 10^{5}$ cells, respectively. The profile of changes in these levels was analogous with that in MTT reduction assay (see Fig. 1).

Recent studies suggest the molecular mechanism responsible for the translocation of cytochrome $\mathrm{c}$ from mitochondria to cytosol during apoptosis. ${ }^{16)}$ As shown in Fig 6, when INS1 cells were treated with $0.3 \mathrm{~mm}$ of alloxan for $4-$ and 6 -h to induce apoptosis, there was a clear increase in cytochrome c amount in the cytosol fraction. These results suggest that alloxan probably induces apoptosis by releasing cytochrome c 
Control

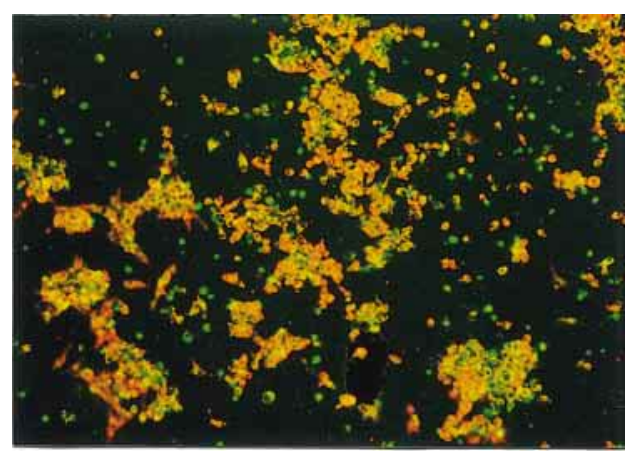

Incubation $4 \mathrm{~h}$

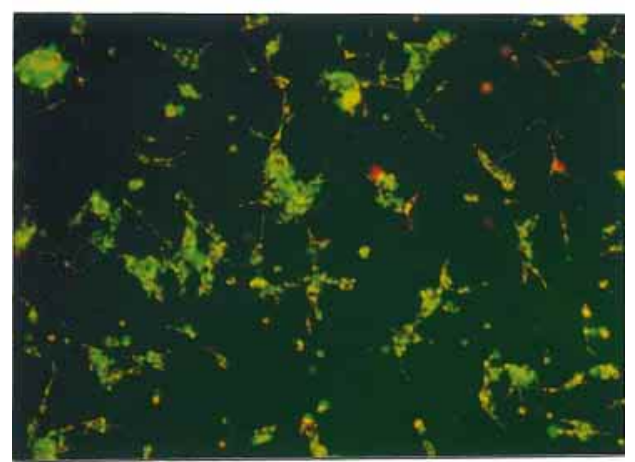

Incubation $9 \mathrm{~h}$

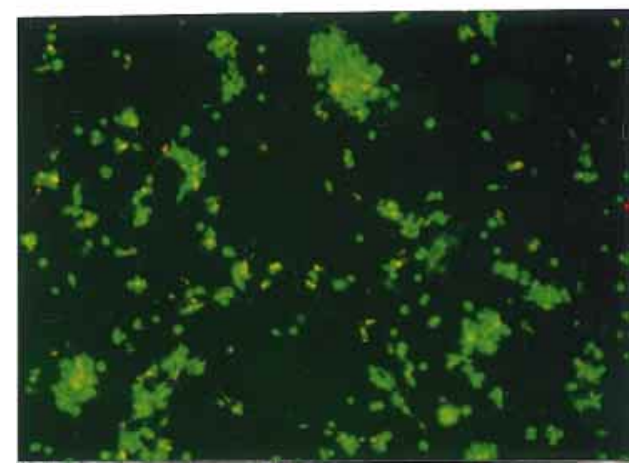

Fig. 7. Effect of Alloxan on Mitochondrial Membrane Potential in INS-1 Cells

After the addition of $0.3 \mathrm{~mm}$ of alloxan, INS-1 cells were incubated for the indicated time. The mitochondrial membrane potential in INS-1 cells was detected by fluorescence microscopy using JC-1 dye. The histological alterations were immediately photographed under fluorescent microscope (Olympus BX 50) through a hand pass filter (magnification, $10 \times 20$ ). Similar results were observed in two other independent experiments using different preparations of cells.

from mitochondria to cytosol in INS-1 cells.

Figure 7 shows the mitochondrial membrane potential of INS-1 cells treated with $0.3 \mathrm{~mm}$ of alloxan for $4-$ and 9-h using a specific fluorescent mitochondrial probe, JC-1. In normal INS-1 cells JC-1 red fluorescence and J-aggregate formation were observed, indicating that the mitochondrial inner membrane built up potential. After treatment with alloxan, the intensity of red fluorescence and J-aggregate formation were gradually decreased with increase of green fluorescence. This result indicates that alloxan causes the collapse of $\Delta \psi$ in INS-1 cells. As shown in Fig. 8, the decrease in red fluorescence and increase in green fluorescence in INS-1 cells treated with alloxan for 24-h was prevented by vitamin $\mathrm{E}$ and BHA. Antioxidants used in this study had no effect on $\Delta \psi$ of control cells. These results suggest that ROS generated from alloxan induces the collapse of $\Delta \psi$ in INS-1 cells.
Alloxan

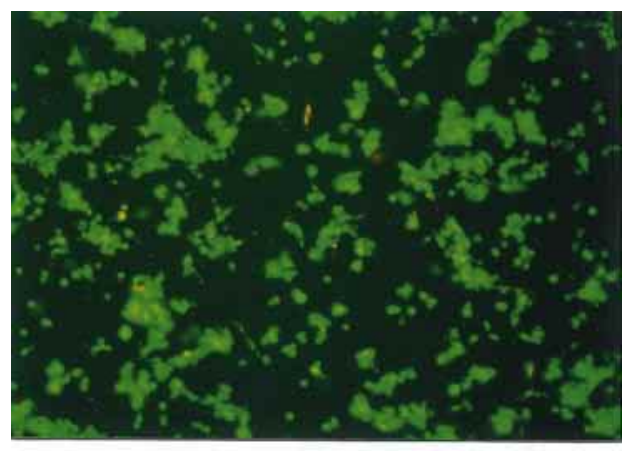

+ vitamin $\mathrm{E}$

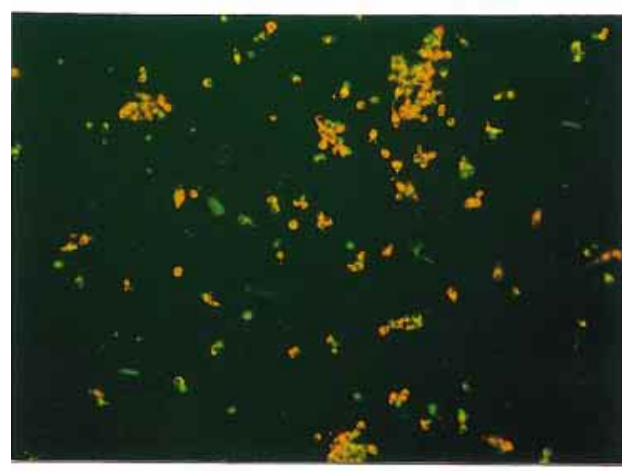

+ BHA

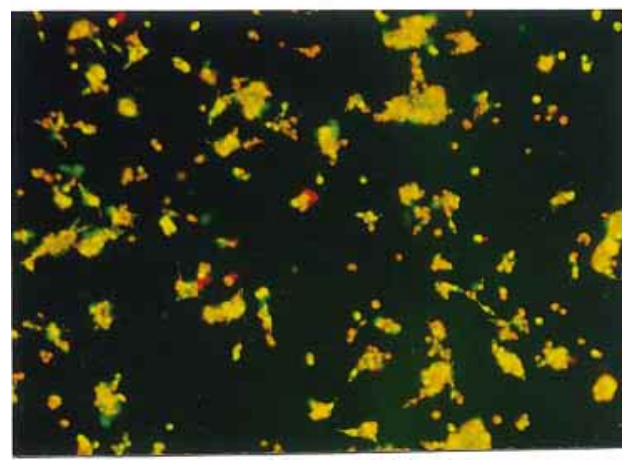

Fig. 8. Protective Effects of Vitamin E and BHA on Collapse of Mitochondrial Membrane Potential of INS-1 Cells Treated with Alloxan

After preincubation with $0.025 \mathrm{~mm}$ vitamin E or $0.1 \mathrm{~mm}$ BHA for $1 \mathrm{~h}$, INS- 1 cells were incubated with $0.3 \mathrm{~mm}$ of alloxan for $24 \mathrm{~h}$. Other conditions were the same as described in Fig. 7. Similar results were observed in two other independent experiments using different preparations of cells.

Selective Toxic Effect on INS-1 Cells We next demonstrated that the cytotoxic action of alloxan is specific for INS-1 cells. Figure 9 shows the effect of alloxan on the number of INS-1 cells compared to that of rat liver RLC-18 cells. Addition of alloxan at $1 \mathrm{~mm}$ to culture medium resulted in a time-dependent decrease in the number of INS-1 cells, suggesting that these cells are sensitive to alloxan. The number of INS-1 cells was $84.4 \pm 8.7$ and $70.3 \pm 11.2 \%$ after $1 \mathrm{~d}$ of exposure to 0.3 and $1 \mathrm{~mm}$ compared with the cells untreated with alloxan, respectively. In contrast, the decrease in number of RLC-18 cells exposed to 0.3 (data not shown) and $5 \mathrm{~mm}$ alloxan was not as marked with various incubation times over $3 \mathrm{~d}$, suggesting that liver RLC-18 cells are resistant to alloxan. These results indicate a positive probability that alloxan inflicts selective damage to the insulin producing cells but not to other cells. 

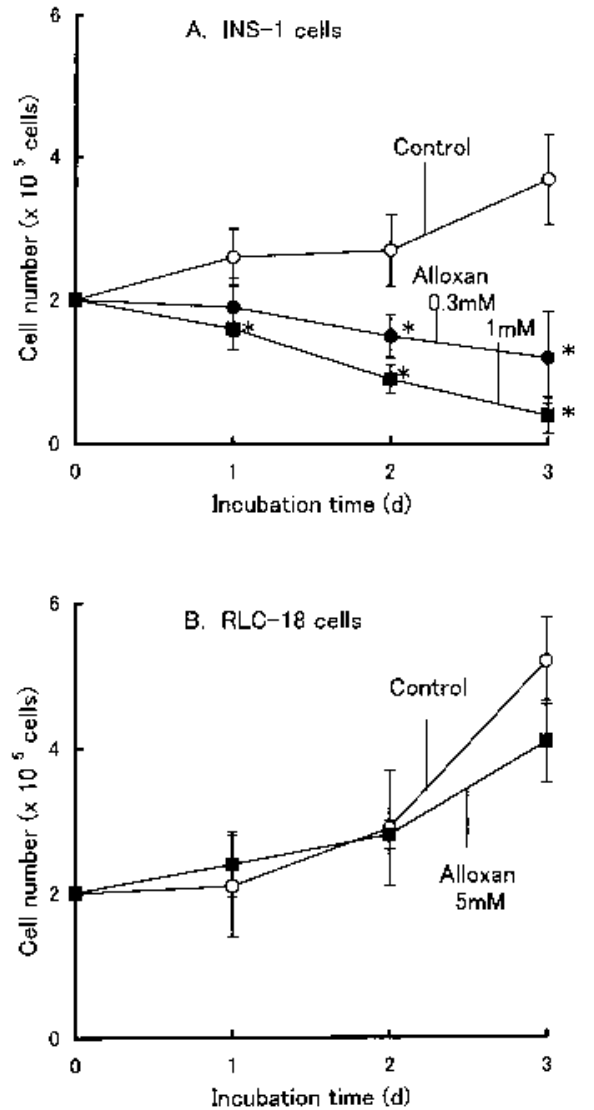

Fig. 9. Alloxan Cytotoxicity to INS-1 Cells and RLC-18 Cells

(A) After the addition of 0.3 or $1 \mathrm{~mm}$ of alloxan to the culture medium, INS-1 cells were incubated for the indicated times, and cell number was counted as described in Materials and Methods. (B) Experimental conditions were the same as described A, except that RLC-18 cells were incubated with $5 \mathrm{~mm}$ of alloxan. Each point represents the mean \pm S.D. of triplicate experiments.

\section{DISCUSSION}

Since alloxan, which has the most potent diabetogenicity, selectively causes pancreatic $\beta$-cell death, ${ }^{1,29)}$ this compound has been used to induce experimental insulin-dependent diabetes mellitus, although the mechanism leading to cell death is not presently understood. We demonstrated that INS-1 cells treated with alloxan at a low concentration below $0.5 \mathrm{~mm}$ for $24 \mathrm{~h}$ resulted in a decrease in viability, intracellular ATP levels, and glucose-stimulated insulin release. The destruction of pancreatic $\beta$-cells by alloxan is a major implication of the onset of diabetes mellitus which is a progressive event occurring over a 24 -h period. ${ }^{1,2)}$ Further, it has been indicated that the diabetogenic concentration of alloxan in the body fluids is $5 \times 10^{-4} \mathrm{M}^{30)}$ This points out the validity of an experimental condition using INS-1 cells treated with alloxan at a concentration below $0.5 \mathrm{~mm}$ over a $24 \mathrm{~h}$ period to elucidate alloxan diabetogenic action.

The present studies demonstrate that treatment with alloxan at low concentration result in a DNA ladder formation and PS exposure in INS-1 cells, suggesting that alloxan induces apoptosis in these cells. DNA strand breaks seem to be responsible for the diabetes mellitus induced by alloxan. ${ }^{10,11)}$ Nonetheless, the cell death associated with DNA strand breaks by alloxan has not been indicated necrosis or apoptosis. To our knowledge, the results described herein are the first to demonstrate that alloxan induces apoptotic cell death, and this finding suggests the possibility that the character of islet DNA strand breaks induced by alloxan injected in vivo may be the form of DNA ladder. When INS-1 cells were treated with alloxan at a low concentration $(0.3 \mathrm{~mm})$, the level of intracellular ATP was a fraction of lowering. Several researchers ${ }^{31-34)}$ have shown that ATP is required for the active execution of the final phase of apoptosis. When cells were treated with alloxan at high concentrations, the significant features of apoptotic death were not observed and the intracellular ATP was completely depleted. The present data can support the earlier proposal that the levels of ATP decide the mode of cell death undergoing apoptosis.

We previously reported that in the $\mathrm{A}^{-}$-generating system of alloxan with GSH in the presence of Fe (III)-EDTA, HO . was generated by $\mathrm{A}^{-}$through a Fenton-type reaction. ${ }^{4)} \mathrm{HO} \cdot$ is powerful initiator of lipid peroxidation. Diabetes is a disease characterized by increased oxidative stress, as indicated by elevated concentrations of lipid peroxidation products in the plasma. ${ }^{35)}$ Slonim et al., ${ }^{8)}$ demonstrated that administration of vitamin $\mathrm{E}$ to rats provided protection against the diabetogenic action of alloxan. Dillard et al., ${ }^{36)}$ demonstrated that in vitamin $\mathrm{E}$ deficient rats alloxan induced an increase in levels of pentane and ethane in the expired breath and thiobarbituric acid reactive substances (TBARS) in plasma, liver and pancreas. Reif et al., ${ }^{37)}$ demonstrated that incubation of alloxan, GSH, and ferritin with phospholipid liposomes resulted in lipid peroxidation. Several antioxidants which reduce $\mathrm{HO} \cdot$ generating prevent alloxan diabetes. ${ }^{1,2)}$ The present results show that vitamin $\mathrm{E}$ and BHA prevent the decrease of intracellular ATP contents, the inhibition of insulin release, the collapse of $\Delta \psi$, and the DNA ladder formation in INS-1 cells treated with alloxan. These results suggest the possibility that lipid peroxidation may play a role in developing the cytotoxicity of INS-1 cells and the validity of the theory that lipid peroxidation is involved in alloxan-diabetes. Vitamin E and BHA completely prevented the cytotoxicity and the formation of DNA ladder, while SOD and thiourea had slight protection. GSH also prevented the formation of ladder. Adding an excess of GSH most likely suppresses the generation of ROS from alloxan through inhibition of the redox cycling reaction between alloxan and dialuric acid in the $A^{-}$generating system. ${ }^{38)}$ Further studies are needed to identify the initiator species and to resolve the mechanism of alloxaninduced lipid peroxidation.

The present study also showed that alloxan decreased intracellular ATP contents and inhibited insulin release, which are strongly dependent on mitochondrial function, as well as collapsing $\Delta \psi$, and releasing cytochrome c from mitochondria to cytosol in INS-1 cells. Other workers demonstrated that alloxan treatment damaged the mitochondrial function. ${ }^{17,18)}$ More recent, evidence has accumulated which supports a direct role for mitochondria in the process of apoptotic cell death. ${ }^{14,15,39)}$ In particular, the collapse of $\Delta \psi$ and the release of cytochrome $c$ have been recognized as one of the early events of apoptosis. ${ }^{40,41)}$ These findings suggest the strong possibility that the mitochondrial damage induced by alloxan is linked to apoptotic INS-1 cell death.

One important issue is the selectivity of alloxan cytotoxicity. We demonstrated that treatment of alloxan leads to a decrease in number of INS-1 cells, but not liver cell line RLC- 
18. Vitamin E and BHA definitely protected INS-1 cells from damage, suggesting the possibility of a low-level defense system against oxidative stress in these cells, compared to that in RLC-18 cells. Indeed, the activity and gene expression of antioxidant enzymes such as SOD, catalase and glutathione peroxidase in pancreatic islets are significantly lower than those in the liver. ${ }^{42)}$ Catalase also contributed to prevention against damage, suggesting an important role of $\mathrm{H}_{2} \mathrm{O}_{2}$ in the process of INS- 1 cell death. These findings may in part explain why INS-1 cells have selective sensitivity to alloxan.

We conclude from the present results that alloxan at a diabetogenic concentration induced apoptosis in INS-1 cells, which was mediated by the impairment of mitochondrial function. This paper serves to delineate the death of pancreatic $\beta$-cells treated with alloxan and should help to clarify the mode of action of this diabetogenic agent.

Acknowledgements We thank Dr. C. B. Wollheim, Geneva, Switzerland, for providing the INS-1 cell lines and Dr. K. Murao, Kagawa, Japan, for helping with the cell cultures. The study was supported by the Hokkaido Foundation for the Promotion of Scientific and Industrial Technology.

\section{REFERENCES}

1) Malaisse W. J., Biochem. Pharmacol., 31, 3527-3534 (1982).

2) Grankvist K., Marklund S., Täjedal I.-B., Nature (London), 294, 158-160 (1981).

3) Dohrmann J. K., Livingston R., Zeldes H., J. Am. Chem. Soc., 93, 3343-3349 (1971).

4) Sakurai K., Miura T., Ogiso T., Chem. Pharm. Bull., 38, 993-997 (1990).

5) Heikkila R. E., Cabbat F. S., Eur. J. Pharmacol., 52, 57-60 (1978).

6) Grankvist K., Marklund S., Sehlin J., Täjedal I.-B., Biochem. J., 182, $17-25$ (1979).

7) Heikkila R. E., Winston B., Cohen G., Barden H., Biochem. Pharmacol., 25, 1085-1092 (1976).

8) Slonim A. E., Surber M. L., Page D. L., Sharp R. A., Burr I. M., J. Clin. Invest., 71, 1282-1288 (1983).

9) Yamamoto H., Uchigata Y., Okamoto H., Biochem. Biophys. Res. Commun., 103, 1014-1020 (1981).

10) Yamamoto H., Uchigata Y., Okamoto H., Nature (London), 294, 284-286 (1981).

11) Uchigata Y., Yamamoto H., Kawamura A., Okamoto H., J. Biol. Chem., 257, 6084-6088 (1982).

12) Dunger A., Augstein P., Schmidt S., Fischer U., J. Autoimmun., 9, 309-313 (1996).

13) Morgan N. G., Cable H. C., Newcombe N. R., Williams G. T., Biosci.
Rep., 14, 243-250 (1994).

14) Green D. R., Reed J. C., Science, 281, 1309-1312 (1998).

15) Zamzami N., Susin S. A., Marchetti P., Hirsch T., Gomez-Monterrey I., Castedo N., Kroemer G., J. Exp. Med., 183, 1533-1544 (1996).

16) Liu X., Kim C. N., Yang J., Jemmerson R., Wang X., Cell, 86, 147157 (1996).

17) Boquist L., Diabetologia, 27, 379-386 (1984).

18) Frei B., Winterhalter K. H., Richter C., J. Biol. Chem., 260, 7394 $7401(1985)$

19) Asfari M., Janjic D., Meda P., Li G., Halban P. A., Wollheim C. B., Endocrinology, 130, 167-178 (1992).

20) Janjic D., Maechler P., Sekine N., Bartley C., Annen A.-S., Wollheim C. B., Biochem. Pharmacol., 57, 639-648 (1999).

21) Janjic D., Wollheim C. B., Diabetologia, 35, 482-485 (1992).

22) Takaoka T., Yasumoto S., Katsuta H., Jpn. J. Exp. Med., 45, 317-326 (1975).

23) Wu D., Cederbaum A. I., J. Biol. Chem., 271, 23914-23919 (1996).

24) Mosmann T. R., J. Immunol. Methods, 65, 55-63 (1983).

25) Sakurai K., Cederbaum A. I., Mol. Pharmacol., 54, 1024-1035 (1998).

26) Fadok V. A., Voelker D. R., Campbell P. A., Cohen J. J., Bratton D. L., Henson P. M., J. Immunology, 148, 2207-2216 (1992).

27) Farber J. L., Lab. Invest., 47, 114-123 (1982).

28) Smiley S. T., Reers M., Mottola-Hartshorn C., Lin M., Chen A., Smith T. W., Steele G. D., Jr., Chen L. B., Proc. Natl. Acad. Sci. U.S.A., 88, 3671-3675 (1991).

29) Rerup C. C., Pharmacol Rev., 22, 485-518 (1970).

30) Lazarow A., "Glutathione: a symposium," ed. by Colowick S. P., Academic Press Inc., New York, 1954, p. 231.

31) Sanchez-Alcazar J. A., Ruiz-Cabello J., Hernandez-Munoz I., Pobre P. S., de la Torre P., Slies-Rivas E., Garcia I., Kaplan O., Munoz-Yague M. T., Solis-Herruzo J. A., J. Biol. Chem., 272, 30167-30177 (1997).

32) Eguchi Y., Shimizu S., Tsujimoto Y., Cancer Res., 57, 1835-1840 (1997).

33) Leist M., Single B., Castoldi A. F., Kühnle S., Nicotera P., J. Exp. Med., 185, 1481-1486 (1997).

34) O’Brien T., Babcock G., Cornelius J., Dingeldein M., Talaska G., Waeshawsky D., Mitchell K., Toxicol. Appl. Pharmacol., 164, 280-290 (2000).

35) Lyons T. J., Diabetic Med., 8, 411-419 (1991).

36) Dillard C. J., Kunert K. J., Tappel A. L., Arch. Biochem. Biophys., 216, 204-212 (1982).

37) Reif D. W., Samokyszyn V. M., Miller D. M., Aust S. D., Arch. Biochem. Biophys., 269, 407-414 (1989).

38) Sakurai K., Ogiso T., Chem. Pharm. Bull., 39, 737-742 (1991).

39) Zamzami N., Marchetti P., Castedo M., Decaudin D., Macho A., Hirsch T., Susin S. A., Petit P. X., Mignatte B., Kroemer G., J. Exp. Med., 182, 367-377 (1995).

40) Bernardi P., Biochim. Biophys. Acta, 1275, 5-9 (1996).

41) Shenker B. J., Guo T. L., O I., Shapiro M. I., Toxicol. Appl. Pharmacol., 157, 23-35 (1999).

42) Lenzen S., Drinkgern J., Tiedge M., Free Radic. Biol. Med., 20, 463466 (1996). 